\title{
ANALISIS AFIKS DALAM BAHASA ARAB, BAHASA INDONESIA, DAN BAHASA INGGRIS
}

\author{
Moh. Nurman \\ M_nurman@gmail.com
}

\begin{abstract}
:
Penelitian ini mencoba mendeskripsikan jenis afiks secara komprehensif melalui analisis afiks dalam tiga bahasa, yaitu: bahasa Arab, bahasa Inggris, dan bahasa Indonesia. Data jenis afiks diambil dari beberapa buku linguistik umum dan morfologi. Data ini kemudian dilengkapi dengan analisis kata berafiks yang ada dalam kamus setiap bahasa tersebut. Hasil penelitian menunjukkan pembagian jenis afiks yang lebih lengkap, yaitu delapan jenis afiks. Kedelapan jenis afiks ini adalah: prefiks, sufiks, infiks, konfiks, interfiks, simulfiks, superfiks, dan transfiks. Dari delapan jenis afiks ini, bahasa Indonesia memiliki jumlah afiks terbanyak, yaitu lima jenis afiks. Sedangkan bahasa Inggris dan bahasa Arab masing-masing memiliki empat jenis afiks.
\end{abstract}

Keywords: Morfologi, Afiks, Prefiks, Sufiks, Infiks, Konfiks, Interfiks, Simulfiks, Superfiks, Dan Transfiks

\section{Pendahuluan}

Afiks adalah morfem terikat yang dilekatkan pada morfem dasar atau akar (Fromkin dan Rodman, 1998:519). Pembahasan mengenai afiks dapat ditemukan dalam setiap buku linguistik umum dan morfologi. Namun demikian, pembahasan pada buku-buku tersebut masih bersifat kurang menyeluruh dan berbeda-beda. Hal ini dapat disebabkan oleh terbatasnya jenis afiks dari bahasa yang dianalisis atau belum adanya analisis yang lebih mendalam mengenai afiks.

Analisis afiks dalam artikel ini akan dibatasi pada tiga bahasa, yaitu: bahasa Arab, bahasa Indonesia, dan bahasa Inggris. Penulis memilih bahasa Arab karena bahasa ini memiliki afiks yang unik yang disebut transfiks (Bauer 1988: 24). Bahasa Indonesia dipilih karena jumlah afiksnya yang cukup banyak. Sedangkan bahasa Inggris dipilih karena jumlah afiksnya yang dianggap hanya dua (prefiks dan sufiks) serta adanya kerancuan klasifikasi infiks (Katamba, 1994: 44-45).
Dalam hal ini, penulis berusaha mencari jenis afiks yang lain dan menjelaskan lebih lengkap mengenai fenomena infiks tersebut.

Dalam menganalisis jenis afiks dari ketiga bahasa ini, penulis menggunakan metode kualitatif. Dalam hal ini, penulis mendeskripsikan jenis-jenis afiks yang ada dalam ketiga bahasa yang diteliti. Dalam mengumpulkan data, pertama-tama penulis mencatat jenis-jenis afiks dan definisinya dari buku linguistik umum dan morfologi. Selanjutnya penulis mencari contohcontoh kata yang berafiks di setiap kamus besar dari ketiga bahasa ini. Penulis juga berusaha mencari kata yang nampaknya berafiks tetapi jenis afiksnya belum pernah diidentifikasi.

\section{Tinjauan Kepustakaan}

Para ahli linguistik membagi afiks dalam jenis yang berbeda-beda. Matthews (1997:11) menyebutkan lima jenis afiks, yaitu: prefiks, sufiks, infiks, sirkumfiks, dan superfiks. Secara umum, Katamba (1993:44) menyebutkan tiga jenis afiks, 
yaitu: prefiks, sufiks, dan infiks. Khusus untuk bahasa Inggris, Katamba (1993:89) mengelompokkan afiks berdasarkan perilaku fonologisnya, yaitu afiks nonnetral dan afiks netral. Fromkin dan Rodman (1998:71-73) menyebutkan empat jenis afiks, yaitu: prefiks, sufiks, infiks, dan sirkumfiks. Alwi dll (1988:31) menyebutkan ada empat jenis afiks dalam bahasa Indonesia, yaitu: prefiks, sufiks, infiks, dan konfiks.

Pengelompokan afiks yang cukup menyeluruh disebutkan oleh Kridalaksana dll (1985) dan Bauer (1988). Kridalaksana dll (1985:19-21) menyebutkan enam jenis afiks, yaitu: prefiks, infiks, sufiks, simulfiks, konfiks, dan superfiks. Bauer (1988: 19-29) membedakan tujuh jenis afiks yang terdiri atas enam afiks segmental, yaitu: sufiks, prefiks, sirkumfiks, infiks, interfiks, dan transfiks; dan satu afiks suprasegmental, yang diistilahkan superfiks atau simulfiks.

Penulis mengumpulkan contohcontoh kata berafiks dari dua kelompok sumber. Pertama dari buku-buku morfologi dan linguistik umum. Kedua dari kamus umum setiap bahasa tersebut. Untuk bahasa Arab penulis menggunakan kamus Al-'Ashri (Ali dan Muhdar, 1996), untuk bahasa Indonesia digunakan Kamus Besar Bahasa Indonesia Edisi ketiga (Alwi ed, 2001), dan untuk bahasa Inggris digunakan kamus Webster's New World College Dictionary Fourth Edition (Agnes ed, 2001). Ketiga kamus ini dipilih karena isinya yang memuat jumlah lema yang cukup banyak dan penggunaannya yang dianggap cukup meluas. Khusus kamus bahasa Inggris di atas, penulis memilihnya karena dalam kamus tersebut ada informasi proses pembentukan kata dari lema tertentu.

\section{Analisis Data}

Dari tiga bahasa yang dianalisis di sini, penulis menemukan sembilan jenis afiks, yaitu: prefiks, infiks, sufiks, sirkumfiks (konfiks), trifiks, interfiks, simulfiks, superfiks, dan transfiks. Penjelasan dan contoh setiap afiks dari ketiga bahasa ini adalah sebagai berikut:

\section{Prefiks}

Prefiks disebut juga awalan. Prefiks adalah afiks yang ditempatkan di bagian muka suatu kata dasar (Alwi dll, 1998: 31). Istilah ini berasal dari bahasa Latin praefixus yang berarti melekat (fixus, figere) sebelum sesuatu (prae). Ketiga bahasa yang dianalisis di sini semuanya memiliki prefiks.

Contoh:

Bahasa Arab: s-g-l 'sibuk' + a- $\rightarrow$ asyghal 'menyibukkan.'

Bahasa Inggris: tangible 'kasat mata' + in$\rightarrow$ intangible 'tidak kasat mata'

Bahasa Indonesia: ajar + meng- $\rightarrow$ mengajar

\section{Sufiks}

Sufiks atau akhiran adalah afiks yang digunakan di bagian belakang kata (Alwi dll, 1998:31). Istilah ini juga berasal dari bahasa Latin suffixus yang berarti melekat (fixus, figere) di bawah $(s u b)^{1}$. Ketiga bahasa yang dianalisis di sini semuanya memiliki sufiks.

Contoh:

Bahasa Arab: $b$-sy-r 'manuasia' $+-i \rightarrow$ basyari 'manusiawi'

Bahasa Inggris: amaze 'kagum' + -ment $\rightarrow$ amazement 'kekaguman'

Bahasa Indonesia: beli +- kan $\rightarrow$ belikan

\footnotetext{
${ }^{1}$ Dalam bahasa Latin, sub- menjadi suc- sebelum c; suf- sebelum f; sug- sebelum g; sum- sebelum m; sup- sebelum p; sur- sebelum r; dan sering juga, sus- sebelum c, p, atau t. Dalam konteks di atas, sub menjadi suf karena pengaruh bunyi $\mathrm{f}$.
} 


\section{Infiks}

Infiks atau sisipan adalah afiks yang diselipkan di tengah kata dasar (Alwi dll, 1998:32). Dalam bahasa Latinnya adalah infixus yang berarti melekat (fixus, figere) di dalam (in). Bahasa Arab tidak memiliki infiks. Bahasa Indonesia memiliki beberapa infiks, salah satunya adalah infiks -em- dalam kata gemetar (dari kata getar). Dalam bahasa Inggris, beberapa ahli bahasa menyebutkan adanya infiks dalam situasi tertentu. Yule (1994) menyebutkan infiks bloody untuk ungkapan emosi, contohnya Hallebloodyluyah! (dari kata Halleluyah). Katamba (1994: 44-45) menyebutkan bahwa infiks hanya ada dalam bahasa Inggris kontemporer yang mungkin tidak digunakan dalam kondisi yang sopan, contoh: in-fuckin-stantiate. Menurut pendapat penulis, satu kata (yang mungkin memiliki lebih dari satu morfem) ${ }^{2}$ tidak seharusnya dimasukkan dalam kategori afiks, karena afiks adalah morfem terikat. Oleh sebab itu, menurut penulis, bahasa Inggris tidak memiliki infiks.

\section{Konfiks}

Konfiks disebut juga ambifiks atau sirkumfix. Secara etimologis dari bahasa Latin, ketiga istilah ini memiliki kesamaan arti. Kon- berasal dari kata confero yang berarti secara bersamaan (bring together), ambi- berasal dari kata ambo yang berarti kedua-duanya (both), dan sirkum- berasal dari kata circumdo yang berarti ditaruh di sekeliling (put around) (Gummere dan Horn, 1955). Menurut Alwi dll (1198:32) konfiks adalah gabungan prefiks dan sufiks yang membentuk suatu kesatuan

\footnotetext{
${ }^{2}$ Kata bloody terdiri atas dua morfem: blood dan y. Kata funkin' juga memiliki dua morfem: fuck dan -ing.
}

dan secara serentak diimbuhkan. Bahasa Arab dan bahasa Inggris memiliki kata yang dibentuk dengan prefiks dan sufiks.

Contoh:

Bahasa Arab: dh-r-b 'memukul'+ ma- dan -un $\rightarrow$ madharabun 'tempat memukul'

Bahasa Inggris: accept 'menerima' + undan -able $\rightarrow$ unacceptable 'tidak berterima'

Akan tetapi, contoh tersebut hanya merupakan kombinasi afiks, bukan konfiks karena tidak secara serentak diimbuhkan. Dalam bahasa Arab, ada kata madharab dan dalam bahasa Inggris ada kata acceptable. Konfiks dapat ditemukan dalam bahasa Indonesia, contohnya kata kelaparan (dari kata lapar). Konfiks ke-...an diimbuhkan secara serentak (tidak ada kata kelapar atau laparan). Kridalaksana dll (1985:20) menyebutkan ada empat konfiks dalam bahasa Indonesia, yaitu: $k e$ ...-an, pen-...-an, per-...-an, dan ber-...an.

\section{Interfiks}

Bauer(1988: 23-24) menyebut interfiks sebagai afiks yang muncul di antara dua elemen yang membentuk kata majemuk. Kata interfiks berasal dari bahasa Latin inter yang berarti berada di antara, dan fixus yang berarti melekat. Dengan demikian, dapat dibedakan dengan infiks yang berarti melekat di dalam. Contoh interfiks dapat dilihat dalam bahasa Arab. Interfiks -ul- muncul di antara kata birr dan walad, sehingga menjadi birr-ul-walad 'bakti anak'. Penulis tidak menemukan interfiks dalam bahasa Indonesia. Untuk bahasa Inggris, penulis berpendapat bahwa bahasa Inggris dapat dianggap memiliki interfiks karena pengaruh bahasa Latin. Contohnya interfiks -o- dalam kata morphology. Morph dan logy memiliki lema tersendiri 
dalam kamus Webster's New World. Gabungan kedua kata ini memerlukan interfiks - $o$ - sehingga gabungannya bukan morphlogy melainkan morphology ${ }^{3}$. Istilah morfologi dalam bahasa Indonesia tidak dapat dianggap memiliki interfiks -okarena hanya kata morf yang ada dalam lema KBBI, tidak ada lema logi.

\section{Simulfiks}

Definisi simulfiks dapat dilihat dari asal katanya dalam bahasa Latin simulatus 'bersamaan, membentuk' dan fixus 'melekat'. Menurut Kridalaksana dll (1985: 20), simulfiks adalah afiks yang dimanifestasikan dengan ciri-ciri segmental yang dileburkan pada bentuk dasar. Dalam bahasa Indonesia, simulfiks dimanifestasikan dengan nasalisasi dari fonem pertama suatu bentuk dasar. Simulfiks masih dianggap hanya terdapat dalam bahasa Indonesia tidak baku, contoh: kopi $\rightarrow$ ngopi. Bahasa Arab dan bahasa Inggris tidak memiliki simulfiks.

\section{Superfiks}

Superfiks atau suprafiks adalah afiks yang dimanifestasikan dengan ciri-ciri suprasegmental atau afiks yang berhubungan dengan morfem suprasegmental (Kridalaksana dll, 1985: 21). Bauer (1988:29) menyamakan istilah superfiks dengan simulfiks. Dari asal kata bahasa Latin, supra berarti di atas (above) atau di luar (beyond), sedangkan simulatus berarti bersamaan. Dari contoh suprafiks dalam bahasa Inggris, 'discount (n) $\rightarrow$ dis'count (v), dapat kita lihat bahwa suprafiks berada pada tataran suprasegmental sehingga istilah suprafiks lebih tepat dari pada simulfiks. Bahasa

\footnotetext{
${ }^{3}$ Bedakan dengan kata archeology yang dibentuk dari kata archeo dan logy, sehingga tidak ada interfiks -o-.
}

Arab dan bahasa Indonesia tidak memiliki suprafiks.

\section{Transfiks}

Transfiks adalah afiks yang muncul di keseluruhan dasar (throughout the base). Dalam bahasa Latin trans berarti disepanjang (across) atau di atas (over). Bahasa Indonesia dan bahasa Inggris tidak memiliki transfiks. Afiks yang termasuk transfiks dapat ditemukan dalam bahasa Arab. Contohnya transfiks $a-a-a$ :

$f-r-h$ 'senang' $+a-a-a \rightarrow$ farraha 'menyenangkan'

$m-d-d$ 'memanjangkan' $+a-a-a \rightarrow$ maddada 'memanjang-manjangkan'

$k-f-r$ 'mengkafiri' $+a-a-a \rightarrow$ kaffara 'menisbatkan kekafiran'

\section{Kesimpulan}

Dari pembahasan jenis afiks di atas, penulis menyimpulkan bahwa dalam bahasa Inggris, ada empat afiks, yaitu: prefiks, sufiks, interfiks, dan superfiks; dalam bahasa Indonesia ada lima afiks, yaitu: prefiks, sufiks, infiks, konfiks, dan simulfiks; dan dalam bahasa Arab ada empat afiks, yaitu: prefiks, sufiks, interfiks dan transfiks.

\section{Pustaka Acuan}

Agnes, Michael (Ed). 2001 (1999). Webster's New World College Dictionary (Edisi ke-4). Cleveland: IDG Books Worldwide, Inc.

Ali, Attabik dan Ahmad Zuhdi Muhdar. 1996. Kamus Al-'Ashri. Yogyakarta: Yayasan Ali Maksum.

Alwi, Hasan dll. 1998. Tata Bahasa Baku Bahasa Indonesia (Edisi ke-3). Jakarta: Balai Pustaka.

Alwi, Hasan (Ed). 2001. Kamus Besar Bahasa Indonesia (Edisi ke-3). Jakarta: Balai Pustaka. 
Bauer, Laurie. 1988. Introducing Linguistic Morphology. Edinburgh: Edinburgh University Press.

Fromkin, Victoria dan Robert Rodman. 1998. An Introduction to Language (Edisi ke-6). Orlando: Harcourt Brace College Publishers. Gummere, John Flagg dan Annabel Horn. 1955. Using Latin. Chicago: Scott, Foresman and Company.

Katamba, Francis. 1994 (1993). Modern Linguistics: Morphology. London: The Macmillan Press Ltd.

Kridalaksana, Harimurti dll. 1985. Tata Bahasa Deskriptif Bahasa Indonesia: Sintaksis. Jakarta: Pusat Pembinaan dan Pengembangan Bahasa.

Matthews, Peter. 1997. The Concise Oxford Dictionary of Linguistics. Oxford: Oxford University Press.

Yule, George. 1994. The Study of Language.

Cambridge University Press 